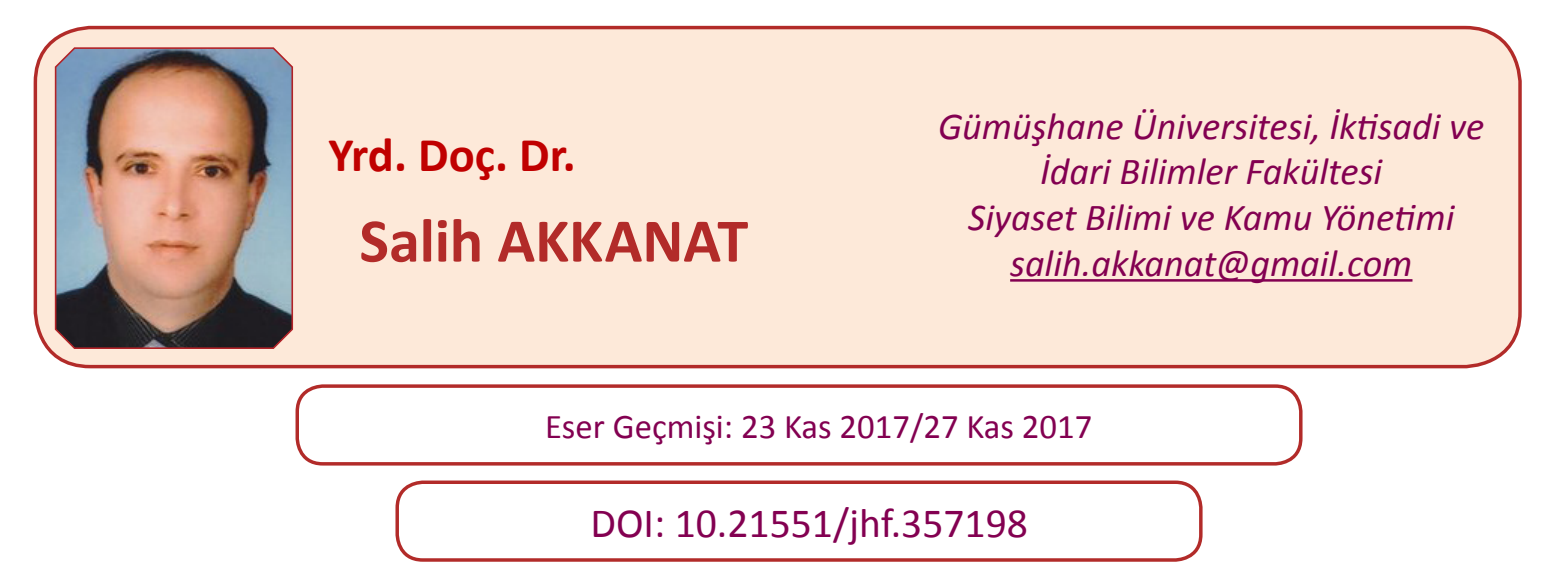

\title{
Kemalist Modernizmin İnşası ve Gelenekçi- Muhafazakârlık: İsmail Hakkı Baltacıoğlu ve Terbiye Düşüncesi
}

\section{Costruction Of Kemalist Modernizm and Tradionalist Conservatism: Ismail Hakkı Baltacioglu And His Philosophy Of Education}

\section{ÖZET}

Bu makale, Kemalist ideolojinin hegemonya alanının yerleşmesinde genellikle göz ardı edilen gelenekçi-muhafazakâr varyantın bazı temel unsurlarını belirginleștirmeyi amaçlıyor. Makale, Kemalizmi dar anlamda bir bürokratik-politik modernleşme projesi olarak, otoriter modernist etkilerle anti-modernist tepkilerin çarpıştığı bir arena şematizmine indirgemek gibi teorik bir basitleşmeden kurtulma olanağına işaret ediyor. Gelenekçi muhafazakârlık, Kemalizmin bürokratik siyasal modernleşme projesinin en temel boyutlarından birini temsil eder. $\mathrm{Bu}$ eklemlenme, özellikle dönemin gelenekçi muhafazakâr yazarlarının yazılarında belirgindir. İ. Hakkı Baltacıoğlu, Kemalist modernleşme projesini Türk gelenekçi muhafazakârlığı ile eklemlemeye çalışan yazarların en önemlileri arasında yer alır. Yazı özellikle onun eğitim ve terbiye düşüncesi ile modernleşme arasında kurduğu bütünleyici ilişkiye odaklanıyor.

Anahtar Kelimeler: Kemalizm, modernleşme, gelenekçi-muhafazakârlık, terbiye, İ. Hakkı Baltacıoğlu

\section{ABSTRACT}

This article aims to highlight some of the key elements of traditionalist-conservative variant of Kemalist ideology which is often ignored in the settlement of its hegemony. The article is pointing an opportunity to get rid of a theoretical simplification about Kemalism and its bureaucratic-political modernization project. Tradionalist conservatism is one of the main dimensions of bureaucratic-political modernization project of Kemalism. İ. Hakkı 
Baltacıoğlu is an important scholar which aims to articulate traditionalist-conservatism with Kemalist modernizatin Project. The article especially focuses on the complementary relationship established by Baltacığlu on the idea of education and modernization Project.

Keywords: Kemalism, modernization, tradionalist-conservatism, education, İ. Hakkı Baltacıoğlu

\section{Giriş}

İsmail Hakkı Baltacıoğlu, terbiye felsefesi üzerine yazılarına meşrutiyet döneminin hemen ardından başlamış, yazılarında çok sık tekrarladığı gibi 'ilmi esaslarla' ve 'titizlikle' terbiye felsefesi üzerinde çalışmayı amaçlamıştır. O’nun düşüncesinde terbiye sadece, mazinin yeni nesillere aktarılarak gelenek hattının sağlamlaştırıldığı bir yöntem değil, daha çok yeni toplum yapısının gereksinimlerine uygun tarzda fertler yetiştirmektir. Tanzimat ve Meşrutiyet'ten Cumhuriyete geçiş sürecinde değișen ve değişmesi lazım gelen terbiyenin işlev ve amaçlarından bahsederken, Cumhuriyet'in milli kimlik kurgusundan ideal yurttaş anlayışına, Durkheim ve Spencer sosyolojisinin de etkisiyle organik ve hiyerarşik toplum fikrinin ulus-devlet anlayışı içinde yapılandırılmasına ve gerekçelendirilmesine kadar geniş bir alan üzerinde Kemalist kuramlaştırmaya katkıda bulunmuştur.

Uygulamada sorunlar çıkmış olsa bile bugün, Türk muhafazakâr sağ siyaset düşüncesi içinde benimsenmesinin de kanıtladığı gibi, geleneksel ve muhafazakâr değerler ve idealler etrafında birleşen toplum nezrinde radikal cumhuriyet modernizminin kabul bulmasında dönemin gelenekçi-muhafazakâr çizgideki aydınlarının katkısı yadsınamaz. Genellikle Kemalist toplum ve siyaset vizyonuyla muhafazakârlar arasındaki eklemlenme, yenimuhafazakârlık olarak adlandırılan düşünce çizgisi üzerinden gerçekleşir. Klasik anlamda muhafazakârlık, 'kültürel yozlașma' kavramı altında, sanayileșme, kentleșme ve kapitalist ekonominin gelişmesine paralel olarak ilerleyen modernlik ve değişme fikrine karşı gelir (Ergil, 1986: 140). Klasik muhafazakârlığın politik ve ekonomik toplum tasavvuruna yön veren düşünce, bu yozlaşmanın tahribatından sürekli gelişme ve ilerleme içinde olan bir dünyada nasıl kaçınılması gerektiğidir. Yeni-muhafazakârlığın 'sürece' odaklanması ve ona karşılık bulmasının 'gerilimi' ise farklıdır. Yeni-muhafazakârlık, şimdiye değin varlığını sürdürebilen kurum, uygulama ve değerleri son derece heterojen ve parçalanmış durumda olan geçiş sürecindeki toplum yapısının henüz tam yerleşmemiş kültürel ortam ve değerleriyle uzlaştırmayı amaçlar (Ergil, 1986: 140). Bu bakımdan Türk-gelenekçi muhafazakârlığının 'felsefi ve siyasal bir dil olarak berraklaştığı kritik dönem olarak, radikal modernizm tasavvurunun politik uygulamalara dönüştüğü erken cumhuriyet dönemi'nin gösterilmesi tesadüf değildir (İrem, 1997: 54).

Baltacıŏglu'nun terbiye düşüncesi de yeni toplum ve düşünce dünyasının gerekleriyle gelenekleri uzlaştırmayı dener. Terbiye yoluyla Cumhuriyetin yeni kuşakları, köklerini ve geleneklerini unutmadan ve hatta bu kökleri hatırlamanın sağladığı üstünlük duygusunun öz-güveni içinde, ulus-devletin bir 'parçası' olma rolünü içselleştireceklerdir. Baltacıoğlu'nda terbiye ve pedagoji, kültür ve gelenek vurgusuna rağmen etkileşimlerle oluşan bir tarihe 
ve ulus fikrine gönderme yapmanın ötesinde Türk ırkının altını çizer. Bu bakımdan yenimuhafazakârlığın Kemalist öğreti içindeki rolü kesindir. Diğer taraftan Kemalist eğitim ideolojisinin öngördüğü yurttaş tipinin 'paternalist' bağlantıları, sosyal ve kültürel bir kurum olarak aile, ebeveynlerin, mürebbilerin, ustaların 'gerçek' hayata intibak sağlamada terbiye edici ișlevleri vurgulanmak suretiyle sağlanmaktadır.

Baltacıŏlu düşüncelerini sistematik bir düzene koymakta yalnız değildir. Kadro aydınlarının Kemalizmi pozitivist-modernist bir doğrultuya yöneltme gayretleri karşısında Baltacıoğlu'nun Yeni Adam ve Peyami Safa'nın Kültür Haftası dergileri etrafında toplanan yeni-muhafazakâr çizginin öncü isimleri, 'ananeci', 'şahsiyetçi', 'ahlakçı' ve 'muhafazakâr' ilkeler temelinde Kemalizme ve yeni topluma şekil vermeye çalışmışlardır. Bu grubun ortak özelliği, materyalizm, bilimcilik, akılcılık, islami tepkicilik ve tutuculuk, dini skolastisizm, marksizm, kozmopolitanizm, entellektüelizm, Aydınlanmacılık, formalizm, liberalizm, ferdiyetçilik ve cemiyetçilik karşıtlığıdır (İrem, 1997: 62) İsmail Hakkı Baltacıoğlu'nun terbiye düşüncesinden hareketle, yeni-muhafazakâr çizginin rehberlik edindiği ilkelerin çerçevesini oluşturduğu Kemalist muhafazakârlık ve milliyetçilik anlayışı açıklık kazanabilir. Özellikle Kemalist eğitim anlayıșının öngördüğü yurttaş profili, ulus ve toplum görüşü ve demokrasi vizyonu ile Baltacıoğlu'nun fert ve toplum terbiyesi üzerinden bu konularda geliştirmiş olduğu gelenekçi-muhafazakâr yorum arasındaki yakın ilişki, Kemalizmin 'ilerici' ve 'çağdaş' olma niteliğinin pek fazla vurgulanmayan 'muhafazakâr' veçhesine açıklık getirebilir. Bu amaçla önce Baltacıoğlu'nun terbiye düşüncesi üzerinde durulacak daha sonra Kemalist eğitim anlayışı ile olan bağlantıları vurgulanmaya çalışılacaktır.

\section{Tanzimat'tan Cumhuriyet'e Pedagoji}

Baltacıoğlu ferde yerel ve milli bir karakter ve öz izafe eder; böylece tüm soyut kavram ve düşüncelere karşı olan nefretini ilan ederken, evrenselliğe de karşı olduğunu belirtir. Genel olarak dinin ve özel olarak da İslam'ın, 'hayat sahasında' hareket ve hürriyet mesafesini kaplayacak denli ağırlığının olmasını eleştirir. Cumhuriyet öncesi döneme yönelttiği eleştirilerin başında dinin sadece 'itikat' alanında değil 'ahlak, hukuk, iktisat' gibi toplum hayatının bütünü üzerinde taşıdığı rol gelir (Baltacıoğlu, 1930a: 6). O’na göre Tanzimat, ferdin 'bedende, fikirde, duyguda ve harekette hür ve serbest olması için lazım gelen' din çemberinin genişlemesini sağlayarak 'muasır medeniyetlere mahsus olan istiklali kazanma' kazanma yolunda önemli bir adım atmasını sağlamıştır (Baltacıŏlu, 1930a: 6). Tanzimat'la birlikte başlayan Türkiye’nin ‘Orta Zaman'dan çıkış süreci 1908 Meşrutiyet inkılabı ile daha da pekişmiştir. Ancak, söz konusu süreç yönetsel ve siyasi anlamda 'eski düzen' karşısında bir kırılmayı temsil ediyorsa bile, terbiye konusunda Tanzimat okulları 'aynı vücut sefaleti, aynı iskolastik, aynı sırrilik, aynı şahsiyetsizlik' içinde 'eski kıymetleri' 'ruhlara ekmekte' idiler (Baltacıoğlu, 1930a: 6). Anayasal, kurumsal ve siyasal atılım, 'asrileşmek hususunda' yeni bir toplum oluşumu için elzem olan fikir terbiyesi, kalp terbiyesi, ahlaki şahsiyetin inkişafı hususunda gerçekleşmemişti. Oysa Baltacıoğlu'na göre Meşrutiyet'in getirdiği hürriyet, adalet ve musavat mefkûrelerinin 'ilim ve medeniyet' değerleriyle desteklenmesi gerekirdi. Meşrutiyet pedagojisi, 'bedende, duyguda, fikirde, fiilde hürriyetten ibaret bir şahsiyetçilik' kurmaya çalışmışsa da eski düzeninin temelleri çok derin ve sağlam olan skolastik anlayışını yıkmak mümkün olmamıştır. 
Yine de Baltacıoğlu, 1916’ya doğru Türk eğitiminde Avrupa milletlerinin eğitim sisteminde olduğu gibi, 'müspetçi, tabiatçi, şahsiyetçi bir maarif' haline gelmek yönünde önemli mesafeler katedildiğini vurgular (Baltacıŏ̆lu, 1930a: 6). Baltacıoğlu'na göre Meşrutiyet pedagojisinin amacı 'adam, vatandaş, kuva ve kabiliyeti mükemmel insan yetiştirmek[tir]' (Baltacıoğlu, 1930a: 6); o amaçla kendi yazmış olduğu 'Coğrafya'nın tedrisi usulü, Hendesenin tedrisi usulü, El işlerinin tedrisi usulü' gibi kitaplarında her dersin toplumsal amaç ve işlevlerini vurgulamak ve yeni müfredatı 'içtimai' ihtiyaçlar temelinde oluşturmak yerine, sadece 'tedris tekniğine' değinmiştir. Bu bakımdan Cumhuriyete gelindiğinde Türk mürebbisi derslerin tedrisinde teknik anlamda son derece gelişmiş bir bilgi birikimine sahiptir ancak Meşrutiyet düzeninin açığa çıkarmış olduğu 'pek mühim ilim ve felsefe' meselelerini kavramaktan uzaktır.

Cumhuriyet devrine kadar eksikliği fazla hissedilmeyen pedagojinin görmeyi ihmal ettiği sorunları Baltacıoğlu üç başlıkta toplar: 'Evvela demokrasi mefkuresinin Türk mürebbilerine tevdi ettiği şahsiyet harci, ikincisi terbiyenin dinin velayetinden tamamiyle kurtularak ilmi ve nasuti bir velayete intikal etmesi, üçüncüsü yeni cemiyatte ilmin ve ilim harsinin aldığı müstesna ehemmiyet' (Baltacıŏ̆lu, 1930a: 6). Böylece dini tefekkürün emrinden kurtulması gereken pedagojinin, yeni bir toplum ve ulus yaratmak yolunda ilmin emrine koşulması gerektiğini, Cumhuriyet vizyonunun gereksinmesi olarak sunma gayretine girer Baltacıŏlu. Terbiye, yeni bir hayatı yoktan var eden sihirli bir güç değil, 'tarihi ve bünyevi sebeplerden dolayı tabiatiyle ve zeruretiyle vücude gelen içtimai inkılapları ruhlarda tesis ede[n]' bir tekniktir (Baltacıoğlu, 1930a: 9).

Yeni bir terbiye için önce yeni bir toplumun oluşması gerekir. Bu durumda pedagoga düşen görev, cemiyet için yeni bir 'mefkure' icadetmek olamaz; yapması gereken cemiyette mevcut halde bulunan yeni hayat 'mefkuresini' terbiye hayatına indirmektir (Baltacıoğlu, 1930a: 9). Dolayısıyla değișen ve yeni bir şekle giren toplumsal hayata uygun düşünce ve eylemde insan yetiştirmektir. Cumhuriyetin eğitim ideolojisi içinde de benzer bir yaklaşımın hakim olduğunu görmek mümkündür. Örneğin 1926 tarihli İlkmektep Müfredat Programı, 'genç nesli muhitine faal bir halde intibak ettirmek suretiyle iyi vatandaşlar yetiştirme[yi]' amaçlar (Üstel, 2004: 131). Bu 'intibak' süreci 'öğrenmeyi olduğu kadar koşullanmayı, uyum sağlamayı olduğu kadar içselleştirmeyi de öngörmektedir'(Üstel, 2004: 132).

Terbiye'nin öznesi fertler olduğu kadar toplumdur da; değişme dönemlerinde düzen ve istikrarın sağlanması toplumun disiplin altına alınmasından geçer. Bundan böyle 'tefekküre, felsefi zihniyete, terkipçi zekâlara ihtiyaç gösteren hakikaten milli ve insani muammalardır. O halde pedagojiyi yalnız bir usulü tedris ananesi şeklinde teşhir eden eski telakkiden biraz uzaklaşmak, gayeler ve felsefeleri üzerinde çalışmak zamanı artık gelmiştir' (Baltacıoğlu, 1930a: 8).

\section{Terbiye Felsefesi ve Umumi Pedagoji}

Cumhuriyet pedagojisi, fertlerin salt teknik güce vakıf olduğu kanaatkâr eğitim anlayışından daha fazlasına ihtiyaç duymuştur. Eğitim ve ulusal bilinç arasında yapısal bir ilişki vardır. Dolayısıyla ulusal birlik duygusu etrafında kültürün seferber edilmesi fertlere hitap eden bir eğitim dilinden çok kitleye ya da 'yığına' hitap eden bir dil gerektirir. Cumhuriyet ideolojisinin ihtiyaç duyduğu pedagojide, fertlerin 'hususi' eğitiminden çok ulusal bilinç doğrultusunda 'umumun' eğitilmesi önem kazanır. Cumhuriyet toplumunda pedagoji 
artık yalnız 'çocuk terbiyesini tetkik etmez; ferdin bütün terbiye hayatındaki hadiselerini terbiye eder...yeni zamanlarda çocuk, genç, ihtiyar, bütün insanların terbiyesi endişelere, mülahazalara zemin ol[maktadır]' (Baltacıoğlu, 1930b: 32) .

$\mathrm{Bu}$ doğrultuda Baltacıoğlu'nun terbiye tanımı ve pedagoji anlayıșı ile Kemalist eğitimin hizmet ettiği idealler arasındaki bağlantılar açıklık kazanır. Sınıfsız ve imtiyazsız bir toplum idealinin gerçekliği, eğitim ve pedagojiye atfedilen rol ve işleve bakıldığında yerini, işbölümüne dayalı, kişilerin 'vasıflarına' göre sınıflandırıldığı ve o sınıfın özellikleriyle donanımlı olduğu, yine de herkesin ulusal ülkü altında eşitlendiği organik ve hiyerarşik toplum yapısının doğallaştırıldığı bir düzen fikrine bırakır. Atatürk'e göre köylü, çiftçi, sanayi erbabı, işçiler 'hep birlikte halkı meydana getirirler' (Kaplan, 2002: 134). Bu nedenle 'bütün halkımızın bilumum fertleri bir diğerinin yardımcısı ve kollayıcısıdır. Bir diğerinin çalışmalarının sonuçlarına muhtaçtır' (Kaplan, 2002: 134). Demokrasinin halkın hâkimiyeti demek olduğunu ve demokraside 'sınıf, imtiyaz, asalet' ten bahsedilemeyeceğini söyleyen Baltacıoğlu da, demokrasinin bir 'iş ve istihsal milleti' (Baltacıoğlu, 1930a: 19) olduğunu söyler. 'Bu müsavat ve iş unsurunu tanımayan, onu herhangi terbiyevi, ahlaki mülahaza ile olursa olsun, ikinci veya sonuncu bırakan bir pedagoji demokrasi zıddı bir pedagojidir' (Baltacıoğlu, 1930a: 20). Güçlü bir toplum yapısı için, fertlerin bireysel tecrübeleri ve yalnız başına ele alınmaları kâfi gelmez; bunun için 'içtimai, ahlaki tesanüdün tabii ve salim bir iş bölümünün' gerçekleștirilmesi gerekir. Cemiyet, Baltacıŏ̆lu için, 'fertlerin yekûnu değil, belki zümrelerin vücude getirdiği yine bir zümredir' (Baltacığlu, 1930a: 22). Bu amaçla, 'sağlam cemiyet için, sağlam şahsiyetler' yetiştirmek gerekir (Baltacıoğlu, 1930a: 23). Mürebbi, bu nedenle, ferdi herşeyin üstünde gören, 'hafıza, zeka, muhayyile' gibi fertçi yeteneklerle meşgul olan bir pedagoji anlayışı yerine, ferdin toplum hayatı içindeki yeri ve öneminden hareketle 'ilmi, iktisadi, ahlaki, bedii hatta ali şahsiyetle mücehhez insanın teşekkülü[ne]' yönelmelidir. İște bu nedenle yeni toplum hayatının ihtiyaç duyduğu pedagoji, 'tedris pedagojisi' yerine 'teşkilat pedagojisi' olmak zorundadır (Baltacıoğlu, 1930a: 16). Baltacıoğlu'nun deyimiyle 'burjuva' fikirlerine hizmet eden, 'hür tahsil, hür meslek, hür san'at fikrinin' tecellisi olan programların yerine, 'el işi resim, bahçe, mutfak, marangozhane, demirhane işleri' gibi iş ve halk pedagojisine yönelmek demokratik toplumun da bir gereğidir (Baltacıŏlu, 1930a: 19).

Baltacıŏ̆lu terbiyenin işlevini açığa çıkarmak, gerekliliğine inandırmak amacıyla doğal yaşam ve toplumsal hayat arasında benzerlikler kurar. Doğal yaşam içinde hayvanlar arasında cinslerine göre doğaya uyum sağlamak bakımından farklılıklar olduğu gibi 'aynı medeniyet içinde muhtelif sınıflı, muhtelif seviyeli insanlar[ın] terbiyesi' arasında da farklar vardır (Baltacıoğlu, 1930b: 8). İster umumi muhit içinde olunsun isterse mesleki bir muhit, terbiye 'insanın muhitinden aldığı itiyatlardır'(Baltacıŏ̆lu, 1930b: 6). Muhitin insanın üzerinde bıraktığı değișmez özellikleri olduğunu söyler Baltacığlu. O'na göre 'terbiye= (muhit, fert)'tir (Baltacıoğlu, 1930b: 15). Ferdi hayvanlar gibi kendi kendine büyüyen bir mahluk olarak tanımlamak kafi değildir; toplumsal bir varlık olan insanın tekamül edebilmesi için ikincil sosyalizasyon kurumlarına ihtiyacı vardır. Bu anlamda terbiye, 'reşit ve kâmil bir neslin sabi ve acemi bir nesli içtimaileştirmesidir' (Baltacıŏ̆lu, 1930b: 6).

Baltacıŏlu için terbiyenin en önemli özelliği ferdin 'mücerret' bir topluma değil 'muayyen' bir topluma 'tetabuk' ettirilmesidir. 'Mücerret' fikirler doğrultusunda ferdin terbiye edilmeye çalışılması eski pedagojinin özelliğidir (Baltacıoğlu, 1930b: 8). Bütün zamanlarda ve mekanlarda geçerli, evrensel bir terbiye kuralı yoktur; toplum hayatı ve müesseseler 
sürekli değiştiğine göre, terbiyede değişmelidir. Tarih ve etnografya, Baltacıŏ̆lu için soyut fikirlerden müteşekkil bir insan tasavvurunun varlığından değil, 'cemiyetlerle ve cemiyetteki hususi muhitlerle' birlikte değișen adamların varlığından bahseder (Baltacıoğlu, 1930b: 8). Bu bağlamda terbiye, 'ferdin insiyaklarını muhite göre tanzim etmek demektir' (Baltacıŏlu, 1930b: 37). Örneğin, Yunanlılarda terbiye, 'adaletin neşvünemasına müsait bir zemin olmuştu. Cermenlerin terbiye muhiti, nizam ve kanun adamı yetiştirmek için, Anglosaksonların terbiye muhiti istiklâl ve ferdiyet sahipleri yaratmak içindir'(Baltacıoğlu, 1930b: 38) 0 halde terbiyeyi farklı muhitlerde farklı amaçlara neyin yöneltmiş olduğunu sorar Baltacıoğlu (Baltacıoğlu, 1930: 38). Bu, kültüre ve millete ait değişmez özellikler ve 'insiyaklar' olduğu düşüncesinden hareketle yanıtlanabilecek bir sorudur. Her muhit kendine özgü bir fert anlayışına sahiptir. Bu durumda her muhit, 'itiyatların neşvüneması için elzem olan aksülâmelleri temin ede[rek], bir takım aksülâmelleri davet etmeyip muattal bıra[karak], her iki gayeye muvafık olan mepsut yahut mâhut diğer itiyatlara müracaat ede[rek]' (Baltacioğlu, 1930b: 40) ferdi evrensel ve mücerret bir toplum anlayışının uzağında 'kendi' çevresiyle uyumlu ve barışık hale getirebilir. Dolayısıyla mürebbilere düşen görev, 'muhitin verdiği terbiyeyi ikmâl ve tanzim etmektir. Şu halde mürebbinin gayesi ait olduğu memleketin muhitine göre değișecektir' (Baltacığlu, 1930b: 119).

Baltacıoğlu muayyen-mücerret ayrımından yola çıkarak, cumhuriyet ve demokrasi değerlerinin görelileștiği bir sonuca ulaşır. Toplumların karşılaştırmalı bir analizinden gücünü alan evrensel bir fert anlayıșı ve demokrasi yorumu, kültüralist bakış için tehlikelidir. Meşrutiyet devrinden farklı olarak demokrasi mefkûresinin ışığında Cumhuriyet devrinde pedagojinin amacl, 'herhangi bir mefkûreye göre adam yetiştirmek değil, zamanın türk cemiyetinin muhtaç olduğu nazari ve ameli fakat hakiki adamı yetiştirmektir' Ona göre 'milli şartların emrinde olmayan, mücerret hukuk formüllerinden doğmuş bir demokrasiye ne tarihte ne de bugünkü dünyada rastlan[mıştır]' (Baltacıoğlu, 1943: 2). Baltacıoğlu'na göre demokrasi de cumhuriyet gibi bir rejimdir ve "her siyasi rejim gibi uyarlandığı sosyal gövdenin tabiatına göre' gelişir, bu nedenle 'demokrasi yok demokrasiler vardır... öyle demokrasiler vardır ki bazı ana prensiplerinde zıtlık görülür. Demokrasi sözünü yalnız kullanmamalı, milleti ile birlikte kullanmalı ki anlașılsın’ demektedir (Baltacıoğlu, 1944: 2). Böylece Baltacıoğlu cumhuriyet ve demokrasi rejiminin kültürel dinamiklerden beslendiğini iddia eder. Bu nedenle demokratik bir toplumda, 'kastın bir zerresi' olmanın ötesinde 'hem fikren' 'hem de fiilen' son derece 'fail' konumundaki fert 'Cumhuriyetin şahsiyeti' olmak hasebiyle kendi kültürel ve milli kökleriyle bağlı olmalıdır (Baltacıoğlu, 1931: 63).

'Cumhuriyet şahsiyetinin tekâmül etmesi', bir 'gençlik teşkilatının' ortaya çıkması, 'mektepsiz ve yurtsuz gençleri yetiştirmek, barındırmak için değil, doğrudan doğruya Türk kültürü ve asri medeniyet tekniğiyle onları kuşatmak için bir gençlik kurumu[nun]' varlığına ihtiyaç duyar ((Baltacıoğlu, 1950: 29). Bu kurumun amaçlarını Baltacıoğlu şöyle tanımlar: 'Türkiye'nin bütün gençlerine toplu hayat yaşatmak; onlara müşterek mesuliyet duygusunu aşılamak; onlara kolektif neşeyi tattırmak; onlara Türk rejimi istikametinde bir moral vermek; onlara yürüyüş, musiki, tiyatro, edebiyat zevklerini vermek; onlara yeni umaniyeti, yani ilimciliği, endüstriciliği, müsavatçılığı aşılamak' (Baltacıoğlu, 1950: 29-30). Cumhuriyet Halk Partisi'nin beşinci kurultayında kabul edilen 1939 tarihli parti programının, 'Yı̆̆ını Yetiştirme ve Halkevleri' bölümüne atıfta bulunan Baltacıoğlu 'Türkün derin tarih ve medeniyetini bilmesine fevkalade ehemmiyet veren... klasik okul terbiyesinin dışında yığına devamlı ve yeni Türkiye'nin ileri gelişme yollarına uyar bir halk terbiyesi vermeyi mühüm 
gören’ anlayışı yücelterek, Cumhuriyet yurttaşının sahip olması gereken nitelikleri hakkında fikir verir (Baltacıoğlu, 1950: 40).

Eflatun'un terbiyeyi vücut ve ruh güzelliğinde arayan yorumu da, Çiçero'nun terbiyeyi çocuğu insan haline getirme sanatı şeklinde anlaması da, Rousseau'nun terbiyeden insanın doğal eğilimlerine geri çekilmesi ve bozulmamış saflığın öğrenildiği bir yöntemi anlaması da tümüyle mücerret ve müphem fikirlerdir, olandan değil olması gerekenden bahsederler; bu nedenle ferdin terbiyesinde usul oluşturamazlar (Baltacıoğlu, 1930b: 21). Baltacıoğlu'na göre bu tanımların tümü terbiyenin gerçek kapsamı hakkında fikir vermekten uzaktır. Dolayısıyla bunlar belki 'terbiye siyasetince' makul görülebilirler ancak hiçbir zaman 'ilmi' bir terbiye tanımı vermezler (Baltacıoğlu, 1930b: 32). İlmi bir terbiye anlayışı, toplumun gerçek hayatı içinden 'kendi sebep ve kanunlarına tabi' tutulduğunda geçerlilik kazanır. Bu bakımdan Durkheim'ın terbiye tanımının ilmi olduğunu söyler Baltacıoğlu: 'terbiye, ergin nesillerin, içtimai hayata elveriş̧li olmayanlar üzerinde yaptığı tesirdir' (Baltacıoğlu, 1930b: 32). Toplumsal hayatın sürekliliğini sağlamak terbiyenin en önemli işlevleri arasındadır. Mazinin kurumlarını bugüne taşımak anlamında değil, değişen toplum yapısına göre fertleri tanzim etmek anlamında terbiye toplumsal sürekliliği sağlar. Değişen toplumun, aşiret ya da kabilevi olması durumunda terbiyeye ihtiyaç yoktur. Ancak sanayileşme ve kentleşmenin getirdiği toplumsal farklılaşma ve gelişme ortamında, farklı seviye ve sınıfların ortaya çıkmasıyla birlikte toplumda farklı işlevlere sahip fertlere ihtiyaç vardır. Bu 'taksimi amel ve ihtisas devri[nde]' bu amellere ve mesleklere göre adam yetiștirme ihtiyacı önem kazanır (Baltacıŏglu, 1930a: 28). Bu gibi durumlarda bir yandan yeni cemiyetin ihtiyaç duyduğu, 'yeni ve fikirli mesleklerin muhtaç olduğu şuurlu yani mütehassıs ve mütefekkir adamları yetiştirmek' (Baltacıoğlu, 1930a: 28) bir yandan da 'müterekki cemiyetin bütün diğer cemiyetlerle hali temasta olan kıymetlerinin masuniyetini manevi istiklâlini gözetmek mütefekkirlerin başlıca vazifesi'dir (Baltacıŏlu, 1930a: 28).

Baltacıŏlu'nun işlevsel ve organik toplum anlayışı içinde her meslek onu uygulayan ferde bazı 'itiyatlar' kazandırır. 'Marangozluk, demircilik, çiftçilik gibi vücutla yapılan işlerin kendisine mahsus bedeni terbiyesi vardır... aynı meslek sahibini şeklinden, vaziyetinden tanımak bile mümkündür. Marangozların, demircilerin, çiftçilerin bir türlü duruşu, yürüyüşü vardır'(Baltacıoğlu, 1930b: 85). Yine Baltacıoğlu'na göre herkesin vücudu 'ailesinin kalıbı içinde yoğrulur. Herkesin vücudü ailesinin meskeninin müsaade ettiği hareketleri, istikamet ve inhinaları kazanır. Ailede mevcut olan şeylerin, aletlerin, vasıtaların mefkudiyet yahut mevcudiyeti de insanların bilhassa çocukların çevikliğine, becerikliliğine bir tesir yapar. Zengin eşyalı ailelerin çocukları yatkın vücutlü, fakir eşyalı ailelerin çocukları da ham vücutlu olur' (Baltacıŏlu, 1930b: 78). Böylece, terbiyenin sadece ustalardan ya da mürebbilerden kaynaklanan bir öğrenme süreci olmadığını aynı zamanda toplumsal ve ekonomik koşulların yansıması olan bir 'kaynaşma' anı olduğunu belirtir. Buradan ulusun hiyerarşik bir toplum örgütlenmesinin yansıması olduğunu anlamak mümkündür; Baltacıoğlu, aile ve meslek karakterizasyonlarından bahsederken mürebbinin terbiye edici işlevinin sınırlarını da çizer. Gerekli ekonomik ve sosyal şartlara sahip olmayanların kapasiteleri, bilgi ve becerileri de sinirlidir.

Terbiye yoluyla ferdin kişiliğinin oluşmasında ve sosyalleşmesinde ebeveynlerin ve mürebbilerin rolü belirleyicidir. Ferdin terbiye yoluyla sosyalleşmesi sadece neyi yapmasının değil neyi yapmamasının telkin edilmesiyle sağlanır. Baltacığlu'na göre ebeveynler ya da 
mürebbiler olmasaydı 'çocuğun yalnız başına tecrübeleriyle muhitinde yaşaması da belki mümkün olmazdı... o halde mürebbilerin terbiyesini yani terbiyenin mürebbi vasıtası ile olan kasti ve şuuri nev'i' (Baltacıŏlu, 1930b: 37) tanımlanacak olursa, 'ferdi muhitine tatbik için mürebbilerin ferdin tabii aksi tesirini tanzim etmeleri ve bu sayede yeni yeni aksi tesirler icat etmeleridir diyebiliriz'(Baltacıŏglu, 1930a: 37). Ferdin asıl terbiye olması bu 'aksi tesirler' sayesinde olur. Sobaya ya da kuyuya yaklaşması istenmeyen bir çocuğun, tokatla tembih edilmesi soba ve kuyunun çocuğa aksi tesir etmesini sağlayacak ve çocuk bir daha istenmeyen davranışta bulunmayacaktır (Baltacıoğlu, 1930b: 37). Baltacıoğlu'nun çocuğun sosyalleşmesi için verdiği örnekler, ulusal-milli kişiliğin oluşmasında 'makbul-makbul olmayan fikirler' ayrımını akla getirmektedir. Cumhuriyet kuşaklarının neyi düşünüp neyi düşünmemelerinin gerektiğini tanzim eden anlayıșı besleyen bir pedagoji mantığı sunar Baltacıoğlu; böylece ideolojiler ve siyaset sahasını düzenleme yetkisini 'eğilimlerin terbiyesi' yoluyla otoritelerin eline verir. Nitekim Atatürk'te bu konuda uyarılarda bulunmuştur 'mürebbilere.' Ona göre 'yazarların ve teorisyenlerin bir taraflı dinleyicisi vaziyetinde kalan Türkiye'nin çocukları hayata çıktıkları zaman...eleştirici, karamsar, milli bilinç ve disipline riayetsiz kitleler teşkil ederler...[bunun önüne geçmek için] genç dimağların öğrendikleriyle memleketin hakiki vaziyet ve menfaatleri arasında irtibat yapmasına yardımcı olmalıdır' (Kaplan, 2002: 140).

Cumhuriyet ideologları, genç cumhuriyet nesillerini Baltacıŏlu'nun ögütlerini dinleyerek terbiye etmiş gibidir. Aklın yerine hisleri koymak, düşünme yetisini heyecanlarla ikame etmek Baltacıŏlu'nun ilmi terbiye analizinin öğütleri arasındadır. Baltacıoğlu'na göre, 'ferdin zihnine fikirleri ithal etmek' yetmez aynı zamanda 'fikirleri hislerle teçhiz etmek', terbiyenin başka bir vazifesi olmalıdır (Baltacıoğlu, 1930b: 58). 'Terbiyenin fiili, heyecanları fikirler etrafında işleterek büyütmek; yahut ataletle öldürmektir. Her iki suretin imkânı, harici, batini müessirlerin zuhuruna bağlıdır. Bu tesirler ise daima fikirlerdir. Terbiyenin bu fikirleri hislere kalbetmesi iki türlüdür' (Baltacıŏlu, 1930b: 58). Birincisi fikirleri hislerle ilişkilendirmektir: 'fikirler vasıtası ile doğrudan doğruya temayülleri ihya ederek, yahut fikirleri mevcut hislere bağlıyarak... ilk defa vatan hissini terkip eden korku, hayat, menfaat, güzellik, taklit... gibi bütün temayülleri uyandıracak surette tarif ve tasvir ederse, bu tarzı talim, vatan fikri vasıtası ile bir takım temayüllerin uyandırılmasıdır ki doğrudan doğruya his terbiyesini teşkil eder' (Baltacıoğlu, 1930a: 58). İkincisi, hisleri görev duygusuyla ilişkilendirmektir: 'acemi nefere askerliği bir vatan vazifesi gibi talim ederek, 'asker ol, silah tut, mevkiini müdafaa et, çünkü vatan senden bunu ister; askerlik vatanperverliktir, silah vatanın namusudur, mevkii müdafaa etmek vatanı sıyanet etmektir'... demek, askerlik hissini vatan hissine bağlamaktır. Vatan hissi acemi neferde evvelce vardı...Mürebbi yeni fikri bu hislere karıştırdı... 'Askerlik Allahın emridir, askeri Allah ta sever, ölürsen şehit, kalırsan gazi olursun!.. diyen Zabit ise ayni talimi Allah ve din hissine bağlıyor demektir. İște gerek fikirleri heyecanlara, gerekse fikirleri mevcut hislere bağlamak suretile fikirler fiillere inkılâp eder' (Baltacıoğlu, 1930a: 58). Baltacıoğlu'na göre, çocuğa ahlakı cana, bedene, açlığa, tokluğu bağlayarak anlatmak gibi terbiye'yi de kendi amaçlarından başka yüce bir ideale bağlamak gereklidir. Şüphesiz ulusal kimliğin oluşmasında umumun terbiyesi içinde benzer bir 'taktik' gereklidir. Örneğin Atatürk'e göre, öğretmenler 'irfan ordusu[na]' mensuptur, çünkü irfan ordusunun görevi 'milletin istikbalini yoğurmaktır... [ve bu görevini] ölen ve öldüren birinci orduya [asker ordusuna] niçin öldürüp niçin öldüğünü öğret[erek]' yerine getirir (Kaplan, 2002: 141). 
Baltacıŏglu terbiyeyi, milli kimliğin yabancı tesirler karşısında aşınmasını engellemenin biraraçolarakgörür(Baltacıoğlu,1930b:87). Gerçimillettıpkıaileve meslekgibi, kendiliğinden ferdi terbiye etmektedir: 'ayni milletin fertleri ayni seciyeleri, ayni terbiyeyi [taşırlar]...ayni fasilenin nebatları gibi -müşterek sıfatlara, milli seciyelere maliktirler' (Baltacıŏ̆lu, 1930b: 86). 'Fert mensup olduğu millet tarafından az çok massedilmeğe mahkumdur'(Baltacıŏlu, 1930b: 86). Böyle olmakla birlikte, nesilleri millileştirmenin en kestirme yolu dil öğrenimidir; zira 'lisan, milliyetin en büyük abidesidir' (Baltacıŏ̆lu, 1930b: 87). Bu nedenle yabancı lisan öğrenimi, özellikle çocuklarda milli bir şuur edinmede geciktirici hatta engelleyici bir etki yapar. Kültürel ve milli yozlaşmanın bir başka çeşidi, sanat, ticaret ve sına'at yoluyla gerçekleșir. Terbiye'nin engel olamadığı bu çeşit etkilenme ve yakınlaşmalardan kaçınmak gerekmektedir. Bu bakımdan Atatürk'te yeni nesillerin yetiştirilmesinde, 'birliği ile ters düşen bütün yabancı unsurlarla mücadele lüzumunu ve milli düşünceleri kemali istiğrak ile her karşıt fikre şiddetle ve fedakarca savunma zarureti telkin edilme[sini]' istemiş (Kaplan, 2002: 138) ve 'yabancı fikirlerden, doğudan ve batıdan gelebilen bütün etkilerden tamamen uzak, milli ve tarihi karakterimizle uyumlu bir kültür' programının zorunluluğuna inandığını belirtmiştir (Kaplan, 2002: 138).

\section{Türkçülüğün Üç Safhası ve İradi Türkçülük}

Baltacıoğlu'nun Kemalizme bağlandığı tek nokta yeni 'terbiye' anlayıșının gözetmesi gereken amaçlarla ideal Cumhuriyet yurttaşının oluşumuna yaptığı katkı değildir. Kemalizm, Baltacıoğlu'nun düşüncesinde bütün Türk tarihi açısından gelinen çok önemli bir aşamayı temsil eder. 'Yakın mazinin' yarattığı hayal kırıklığg ve dünya konjonktürünün zorunlu kıldığı 'değişme fikri' karşısında Kemalizm, Türk'ün ruhuyla yeni düzeni 'temaşa' haline sokacak bir imkan olarak görülür. $\mathrm{Bu}$ çerçevede, Türk modernleşmesine kendi özgünlüğü içinde gelişebileceği bir alan açmak amaçndadır Kemalizmin. Modernleşme ancak Türk toplumuna yön veren ve halen yaşamakta olan kendi tarihsel ve kültürel dinamiklerimizin açığa çıkarılması ve keşfedilmesi yoluyla sağlanabilir. Kemalizm, ideal Cumhuriyet yurttaşının terbiye ve eğitiminde olduğu gibi toplumun baştan ayağa kalkındırılmasında da bu anlayışı rehberlik edinmelidir. Bu açıdan Baltacıoğlu Kemalizmi 'iradi Türkçülük' olarak tanımlar: 'iradi Türkçülük. Atatürk ile Türkçülük tablo gibi temaşa ve istigrak konusu olmaktan çıkar, yaratıcı ve aktif bir varlık olur. Bu safha iradi Türkçülük safhasıdır' (Baltacıoğlu, 1994: 37).

Ancak bu aşamaya gelinmeden önce milli bilinç tarihi açısından Baltacıoğlu için iki önemli evrenin anılması gerekir. İlki Abdülaziz devrinin son dönemleri ile Abdülhamit devrinin ilk zamanları arasında yaşanan 'fikri Türkçülük' devridir. Bu devir 'Osmanlı milleti ve Osmanlı dili[nin] çevirilerde, tarihi ve edebi metinlerde yerini 'Türk milleti ve Türk dili' terminolojisine bırakmasıdır. Millet bilinci bu devirde, 'tarihi müşahede, orjinalite hatsi, milli gramer, mantıki istikra ve istidlaller' şeklinde ortaya çıkmaktadır (Baltacıŏ̆lu, 1950: 34). İkinci evre, milliyet bilincinin 'duygu alanına' girmeye başlamasıyla ortaya çıkan 'romantik Türkçülük' devridir. Bu dönemde Türklük, kıyafetten mimariye, oyunlardan masallara milli olan her şeye bir 'başkalık' ve 'güzellik' atfedilmesi anlamına gelir (Baltacıoğlu, 1950: 35). Panislamizm ve Panturanizm akımlarıyla birlikte romantik milli şuur ideolojik bir görüntü almaya başlar. Türk Ocakları bu romantik milliyetçiliğin 'mabedi' gibidir. Hamdullah Suphi, Mehmet Emin gibi Türkçüler, akımın önderliğini yaparlar. Romantik milliyetçilik Durkheim sosyolojisinden etkilenen Gökalp sosyolojisinde en son 'vuzuhunu' bulur. Buna göre millet, sosyal bir realitedir; dinin işlevi bilim ve milletin dışında görülmelidir; vatan, akli 
bir kurgu olmanın ötesinde tarihi bir olgudur ve fertlerin dışında ve üstünde egemen bir varlık konumundadır (Baltacıoğlu, 1950: 35). Her iki akım da, özellikle romantikler, bilime, ekonomiye ve teknolojiye önem atfetmiş olmalarına rağmen sadece düşünce planında kalmış, daha ileri gidememişlerdir.

Kemalizme gelinceye kadar Türk toplumunun zafiyeti hep dışardan müdahalelerle giderilmeye çalışılmıştır. 'Mazinin enkazı altında can çekişen' Türk'ün hasta vücudundan 'çöken, ölen mazi[sini] atıp, altında henüz sıcak, henüz yaratıcı olan hayat kuvvetini bu[lan] ve onu canlı bir edebiyat, canlı bir ahlak şeklinde cesaretlen[diren]' ve 'ölüden diriye sıçramasını' sağlayan Kemalizm olmuştur (Baltacıoğlu, 1931: 9). Kemalist sıçrama ve 'terakki' hiçbir şekilde mazinin dışına çıkmak anlamına gelmez. 0 ne büsbütün mazinin içinde, ne de büsbütün dışındadır.

Baltacıoğlu muhafazakârlıktan değişmek zorunda kalmış ölü örflere körü körüne bağlılığı anlar ve bu nedenle onu eleștirir (Baltacıŏlu, 1994: 37). Kemalizmin 'maziy[le]' ilşkisine de bu eleștiri bağlamında yaklașır. 'Gelenek' kavramını ingilizce 'tradition'; ‘örf”'ü ise 'opinion' kavramıyla karşılayan Baltacıoğlu'na göre bu kavramlar arasındaki fark geleneğin 'değișmeyen yani bütün zamanlarda canlı ve kuvvetli kalan örfleri tanımak' (Baltacıŏlu, 1950: 34) anlamına gelmesidir, yoksa 'değișmek zorunda kalan ölü örflere ve maziye' saplanıp kalmak değil. Bu bakımdan Kemalizm özü itibariyle ananeci ya da anane düşmanı olmayan bir karakterdeddr. Kemalist hareket, 'heyecan ve irade kahramanlığı olduğu kadar ilmi ve teknik kahramanlığıdır' bu nedenle 'yeni bir millet yaparken, yeni bir tarih yaratırken' bütün 'asri kahramanlık' hareketleri gibi işe 'tarlayı baștan aşağı temizlemek ve yeni binayı yepyeni malzeme ile ve yepyeni nispetlere göre inşa et[mekle]' (Baltacıoğlu, 1931: 61) başlamıştır; zira tarla aynı tarladır.

Kemalist Türkçülük anlayışı, Baltacığolu'na göre Gökalp'in 'din, dil, kültür' birliği şeklinde tanımladığı 'millet' anlayıșını yansıtmaz. Ona göre Gökalp'in millet tanımında kültür, 'sosyal tipten sosyal tipe' değișme göstermektedir (Baltacıoğlu, 1973: 63). Oysa bir sosyal tipten diğerine değişmeyen 'yargılar' vardır ve bunlar gelenek olarak adlandırılır. Kişinin milletini en çok ispatlayan bu yargılardır. Bu yargılar arasında, mitler, masallar, dilin sentaksları, bezeme motifleri ve mimikler saylabilir. Bunlar tarih öncesi devirlerde, toplumların 'doğum' çağında kolektif bilinç altına yerleşirler ve bir daha da ne kaybolurlar ne de bir sosyal tipten diğerine değişme gösterirler. Baltacıoğlu, Ziya Gökalp'in millet fikrinde, kültürün sadece dış özelliklerine göre tanımlandığını söyler; oysa millet gelenek yoluyla 'genetik kodların' nesilden nesile, toplumdan topluma aktarılmasıyla varlık bulur. Bu haliyle Gökalp'in tanımından çok Baltacıŏ̆lu'nun yaptığı millet tanımın Kemalizme yakın olduğunu söylemek mümkün görünmektedir. Özellikle, erken Cumhuriyet döneminde ve Atatürk'ün bizzat katkıda bulunduğu Antropoloji Enstitüsü'nün çalışmaları, Türk Tarih ve Türk Dil Kurumlarının Türk Kimliğini tanımlamak için verdiği çabalar göz önünde bulundurulduğunda, millet anlayışının 'kültür' birliğinden çok 'ırk' birliğine yakın olduğu görünmektedir.

Nitekim Baltacıoğlu, Gökalp'in onun kendi teziyle çelişir biçimde, Kürt mü yoksa Türk mü olduğu buhranına kapıldığını sonrada Türklükte karar kıldığını şöyle anlatır: '[Gökalp] konuştuğu kürtçede, asıl kürtçede olduğu gibi, erkek dişi kelimeler bulunmadığını, türkçede olduğu gibi, konuştuğu kürtçenin de cinsiz kelimelerden oluştuğunu görmüştür. Gökalp bundan anlamış ki, milli dili, kelimeler arasında erkek, diși ayırımı yapmayan bir dildir, 
türkçedir. Bu düşünceden sonra Gökalp türklükte karar kılmış, sonra da en büyük türk bilgini olmuştur'(Baltacıoğlu, 1973: 65). Aynı șekilde Hatay milletvekili Ali Şelhum Devrim'de Atatürk'ün Hatay sorunu sırasında 'siz Türksünüz!' demesi üzerine, mutfakta kullandıkları eşyaların isimlerinin Türkçe kelimelerden oluştuğuna dikkat etmiş ve böylece öz be öz Türk olduğuna kara vermiştir (Baltacıoğlu, 1973: 66). Yine Baltacıoğlu, dönemin Hatay sorunu sırasında bir generalin kendisine 'Hatay'lllar türk oğlu türktürler. Türk olmasalardı, disipline gelirlermiydi?' dediğini aktarır (Baltacıŏ̆lu, 1973: 66).

Bir bilim adamı olarak Türklerin neden büyük bir millet olduğunun 'ispatlanmasında' 'duygu' ve 'sezgi'lerden' öte 'bilimli bir anlayıș' gerektiğini söyleyen Baltacıoğlu, 'milletin millet olarak değerini ölçmek' için gerekli olan 'bilimsel' kriteri, milletin 'medeniyetinden, tekniğinde önce, kültürünü, kamu varlı̆̆ını incelemek' şeklinde belirler (Baltacıoğlu, 1973: 71). Bu bakımdan 'hangi millet sonsuz dil köklerine, dil eklerine sahip ise hangi millet varlığın tümünü kendi eliyle adlandırabilirse o millet büyük millettir' (Baltacıŏ̆lu, 1973: 69). 0 halde 'hangi millet dilinin kökleri Türkçenin kökleri kadar zengindir? Hangi millet dilinin ekleri türkçenin ekleri kadar üreticidir? Hangi millet üniversel varlığı diliyle Türk dili kadar kavrayıcıdır?' Öte yandan 'hangi millet efsanede, mimarlıkta, tiyatroda, felsefede, yaratıcı ise, o millet büyük millettir' (Baltacıoğlu, 1973: 69). O halde, 'hangi milletin efsanesi Oğuz efsanesi kadar zengindir? Hangi milletin mimarlığı klasik Türk mimarlığı kadar insancıdır? Hangi milletin tiyatrosu Türk halk oyunları kadar özlüdür? Hangi milletin halk mizahı Nasrettin Hoca'nın mizahı kadar canlıdır?' (Baltacıoğlu, 1973: 69.). Bu bakımdan yaratıcı komutan ve devlet adamları da 'büyüklük' ispatında kullanılabilir: 'Mete Türktür, İbrahim Peygamber Türktür, Fatih Sultan Mehmet Türktür, Hazreti Mevlana Türktür, Hacı Bektaşi Veli Türktür, Feylozof Farabi Türktür. Atatürk Türktür' (Baltacıoğlu, 1973: 69). Baltacıoğlu'na göre Atatürk bütün bu gerçeklerin farkında olan, duyan ve sezen bir kişiliğe sahipti. Bu düşünceler gelenek kavramı yoluyla 'inşa edilen' bir milli-ulusal kimlik kurgusunun 'ırkçı' yüzü hakkında yeterince fikir vermektedir.

\section{Sonuç}

Özellikle gelenekçi yeni-muhafazakârlığın bir Cumhuriyet ideolojisi olduğu vurgulanmıştır (Çiğdem, 1997: 67); zira kendi varoluşunu Cumhuriyetin radikal modernist uygulamalarına borçludur. Bu bakımdan Baltacıoğlu'nun 'terbiye' ve 'millet' yorumunun gösterdiği gibi Kemalizm ve muhafazakarlık arasındaki ilişki iki düzlemde kurulmaktadır: devlet paternalizmi ve araçsal bir alan olarak medenileşme. Kurucu Cumhuriyet projesinin 'paternalist-organik yapısının muhafazakâr yorumlara son derece müsait' olması bu ilişkinin kurulmasını kolaylaştırmıștır. 'Muhafazakârlık ve Kemalist etik, Aristogil eksende bireylerin doğalarını ancak toplumsal olarak gerçekleștirebilecekleri ilkesini temel alırlar. $\mathrm{Bu}$ Rousseau'nun kavramsallaştırmasıyla genel yararın özel yarar galebe çalmasıdır' (Öğün, 1997: 104). Baltacıoğlu'nun 'terbiye' yorumu Türk toplumunun kolektif yaşamında saklı bulunan 'paternalist kültür kodlarının' varlığından hareketle 'önce cumhuriyetin doğasında yatan paternalist ilkelerle buluşmayı, sonra politik eylemlerin kültürel dünyada yarattığı rahatsızlıkları telafi etmeyi ve son olarak onu tarihsel olarak durduğu noktaya yeniden kavuşturmayı' amaçlar (Öğün, 1997: 104). Ancak geçmişi yeniden yorumlarken, yeni ulus-devlet anlayışının gereksinimleri doğrultusunda bir 'inşa' sürecine tabi tutar onu. Cumhuriyet toplumunun birey anlayışı bir yönüyle bu yeniden okumanın 'kazanımlarıyla' yüklüdür. Cumhuriyet devletinin sorumlu yurttaşı, Türk milli kimliğinin özelliklerini taşır. 
$\mathrm{Bu}$ cumhuriyet ve demokrasi 'mefkuresi'nin sınırlarını çizer; cumhuriyet ve demokrasi değerlerinin görelileştiği bir zemin hazırlar. Mücerret-Muayyen ayrımı yoluyla eğitim ve pedagoji anlayışı milli ve kültürel motivasyonlarla yüklenir. Böylece, Kemalizmin yetkeci paternalist niteliği pekiştirilmiş olur. Baltacıoğlu'nun terbiye anlayışı Kemalist modernizmin muhafazakâr niteliğini görmemize yardımcı olur.

\section{Kaynaklar}

BALTACIOĞLU, İ. Hakkı (a) (1930). Hususi Tedrisat Usulleri, İstanbul: Muallim Ahmet Halit Kitaphanesi.

BALTACIOĞLU, İ. Hakkı (b) (1930). Umumi Pedagoji, İstanbul: Muallim Ahmet Halit Kitaphanesi.

BALTACIOĞLU, İ. Hakkı (1931). Mürebbilere, İstanbul: Sühulet Kütüphanesi.

BALTACIOĞLU, İ. Hakkı (1933). Tarih ve Terbiye, İstanbul: Semih Lütfi Sühulet Matbaası.

BALTACIOĞLU, İ. Hakkı (1950). Halkın Evi, Ankara: CHP Halkevleri Bürosu.

BALTACIOĞLU, İ. Hakkı (1973). Atatürk'ün Kişiliği Devrimleri, Erzurum: Atatürk Üniversitesi Basımevi.

BALTACIOĞLU, İ. Hakkı (1994). Türke Doğru, Atatürk Kültür Merkezi, Ankara

BALTACIOĞLU, İ. Hakkı (22 Temmuz 1943) “Milli Mantığa Doğru”, Yeni Adam, sayı: 4162.

BALTACIOĞLU, İ. Hakkı, “Bizim Cumhuriyetimiz”, Yeni Adam, 26 Ekim 1944, sayı: 513-2.

ERGİL, Doğu (1986). "Muhafazakarlık”, İdeoloji, Milliyetçilik, Muhafazakarlık, Halkçılık, Ankara: Say Yay.

İREM, C. Nazmi (1997). "Kemalist Modernizm ve Türk Gelenekçi Muhafazakârlığının Kökenleri”, Toplum ve Bilim, sayı: 74

KAPLAN, İsmail (2002). Türkiye’de Milli Eğitim İdeolojisi, İstanbul: İletişim Yay.

ÖĞÜN, S. Seyfi, (1997). “Türk Muhafazakârlığının Kültür Kökleri ve Peyami Safa’nın Muhafazakâr Yanılgısı", Toplum ve Bilim, sayı: 74

ÜSTEL, Füsun (2004). “Makbul Vatandaş”ın Peşinde, İstanbul: İletişim Yay. 